RASĀYAN J. Chem.

Vol. 13 | No. 1 |690 - 698| January - March | 2020 ISSN: 0974-1496 | e-ISSN: 0976-0083 | CODEN: RJCABP

\title{
MOLECULAR DOCKING AND MOLECULAR DYNAMIC SIMULATION OF THE AGLYCONE OF CURCULIGOSIDE A AND ITS DERIVATIVES AS ALPHA GLUCOSIDASE INHIBITORS
}

\author{
Nursamsiar $^{1{ }^{*}}$, M. Siregar ${ }^{1}$, A. Awaluddin ${ }^{1}$, N. Nurnahari ${ }^{2}$, S. Nur ${ }^{1}$, E. \\ Febrina $^{3}$ and A. Asnawi ${ }^{4}$ * \\ ${ }^{1}$ Sekolah Tinggi Ilmu Farmasi Makassar, Jl. Perintis Kemerdekaan Km.13,7 \\ Makassar 90242, Indonesia \\ ${ }^{2}$ Faculty of Pharmacy, Bhakti Kencana University, Jl. Soekarno Hatta No.754, \\ Bandung, 40617, Indonesia \\ ${ }^{3}$ Faculty of Pharmacy, Universitas Padjadjaran, Jl. Raya Bandung-Sumedang Km. 21, Jatinangor, \\ Sumedang, 45363, Indonesia \\ ${ }^{4}$ School of Pharmacy, Institute Technology of Bandung, Jl. Ganesha 10, \\ Bandung, 40132, Indonesia \\ *E-mail: nur.samsiar@stifa.ac.id
}

\begin{abstract}
Diabetes mellitus (DM) is characterized by high blood sugar levels caused by insufficient insulin production in the pancreas or insulin resistance in the body. Alpha-glucosidase enzymes are therapeutic targets for type 2 diabetes treatment. Structurally, curculigoside has a resemblance to xathohumol (chalcone) which has a strong inhibitory activity against alpha glucosidase. The present study aims to determine the interaction of the aglycone of curculigoside $\mathrm{A}$ and its derivatives against alpha glucoside (PDB ID 2QMJ) was evaluated based on interaction mode and binding stability by performing docking and molecular dynamic simulation by using AutoDock 4.2 and AMBER 18, respectively. All ligands can interact with alpha glycosidase and ligand 34, 36, 43, and 56 have a best binding mode with free bonding energy of $-6.30,-5.67,-5.16$, and $-5.92 \mathrm{kcal} / \mathrm{mole}$, respectively. The hydrogen bonds formed in MD are different from the docked pose because of a large movement of alpha glucoside receptor and ligand during the MD process. In conclusion, ligand 34, 36, 43, and 56 are candidates for lead compounds as alpha glucosidase inhibitors.
\end{abstract}

Keywords: Aglycone Curculigoside A, Alpha Glucosidase, Chalcone, Docking, MD

(C) RASĀYAN. All rights reserved

\section{INTRODUCTION}

Diabetes mellitus (DM) currently affects 10.3 million Indonesian people and this number is predicted to increase to 16.7 million by $2045 .{ }^{1} \mathrm{DM}$ occurs due to deficiency of insulin secretion by $\beta$-pancreatic cells, increased insulin resistance or damage to insulin action in the target tissue. Type 2 diabetes (T2D) is the most common form of the disease, accounting for approximately $90 \%$ of cases. ${ }^{2}$ The magnitude and time of the peak plasma glucose (PG) depends on a variety of factors, including the timing, composition and quantity of the meal. PG peaks for diabetic individuals about $\geq 200 \mathrm{mg} / \mathrm{dL}$ but in non- diabetic individuals rarely exceed $140 \mathrm{mg} / \mathrm{dL}$ (about 60 minutes after the start of a meal). Thus, controlling PPHG to achieve blood glucose levels such as non-diabetic individuals becomes one of the therapeutic strategies for T2D. ${ }^{3}$ The $\alpha$-amylase inhibitor is a compound that inhibits carbohydrates breakdown into glucose by amylase enzyme. The $\alpha$-amylase is a carbohydrate hydrolase located on the border of the small intestinal epithelial brush ${ }^{4}$ and acts as a catalyst in the final stages of carbohydrate digestion which only monosaccharides such as glucose and fructose can be absorbed by the intestine. ${ }^{5}$

Rasayan J. Chem., 13(1), 690-698(2020)

http://dx.doi.org/10.31788/RJC.2020.1315577

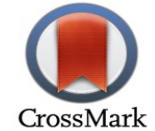


RASĀYAN J. Chem.

Vol. 13 | No. 1 |690 - 698| January - March | 2020

This enzyme breaks down oligosaccharides through the hydrolysis reaction by breaking the 1,4- $\alpha$ glycosidic linkage between glucosil residues and glycosidic oxygen (C1-O) accompanied by proton exchange between water and glucosil residues and resulting D-glucose as a final product that is easily absorbed by the intestine and will cause an increase in postprandial blood glucose levels. ${ }^{6}$ The inhibitory action of this enzyme can effectively reduce the digestion of complex carbohydrates and their absorption which causes decreased postprandial glucose levels in diabetics. ${ }^{4}$

One of the chalcone derivatives which has a strong inhibitory activity against alpha glucosidase is xathohumol with $\mathrm{IC}_{50}$ of $8.8 \mu \mathrm{M}^{7}$ The aglycone of curculigoside A has a structural similarity to the chalcone. The aglycone of curculigoside A is a phenolic glycoside isolated from the rhizome of Curculigo orchioides. $^{8}$ Its aglycone was predicted good in absorption, moderate in permeability, and weak binding into plasma proteins. ${ }^{9}$

In silico, one of the common approaches to determine the mechanism of action of a compound by considering the similarity of chemical structures. The similarity aspect of chemical structure refers to the similarity of chemical elements, molecules as well as substructure compounds. The basic principle is assumed that the similarity of a chemical structure compound will have similar biological properties and compounds with similar structures will tend to bind to the same protein. ${ }^{10}$ Therefore, several studies have been carried out to modify the structure of the lead compound to obtain a more active compound but less toxic both chemically ${ }^{11}$ and in silico ${ }^{12}$.

One method used is molecular docking which is the process of docking a molecule into the active site of the target macromolecule through noncovalent bonds. It is important to know the basic structure of the drug that will be designed to optimize the ligand binding interaction in macromolecules. ${ }^{13}$ Docking is used to predicting the interaction and orientation of ligand binding to the target protein as well as in the virtual screening of several candidate compounds to obtain the best hit for specific targets. ${ }^{14}$

Docking is more focused on poses and interactions of ligands on an active side, to obtain more comprehensive information, it is necessary to simulate through molecular dynamics that provide information about the stability of ligand-protein binding. Although an acceptable binding mode can be provided, the solvent effect and protein flexibility were not fully considered.

Therefore, MD simulations were carried out on the best-docked interaction to further explore the ligandreceptor interactions. In this study, the docking mode and interaction stability of the aglycone of curculigoside $\mathrm{A}$ and its derivatives on $\alpha$-glucosidase was carried out by using docking and molecular dynamic simulation.

\section{EXPERIMENTAL}

\section{Hardware and Technical Specifications}

Computers are equipped with an Intel@ Core ${ }^{\mathrm{TM}}$ i5-7200U CPU @2.50 GHz (4 CPUs, $2.7 \mathrm{GHz}$ ), 8GB of RAM, OS: Windows 10 Home Single Language 64-bit (10.0 Build 17134) and Intel ${ }^{\circledR}$ Xeon ${ }^{\circledR}$ CPU E2620 v4@2.10 GHz, 64 GB of RAM, OS: Linux Ubuntu 16.04 64-bit. Chemical structures of the molecules were drawn using ChemDraw in ChemOffice 8.0. Preparation of macromolecule and ligand were using AutoDock 4.2 and visualization was carried out by using Discovery Studio Visualizer.

\section{Ligand Preparation}

The molecular structures of the aglycone of curculigodise A and its derivatives ${ }^{9}$ were sketched using ChemDraw Ultra software ${ }^{15}$ of ChemOffice and subjected to energy minimization technique using Allinger's molecular Mechanics (MM2) force field followed by geometry optimization using semiempirical Quantum Mechanics based on AM-1 (Austin Model-1).

\section{Preparation of Alpha Glucosidase Macromolecules}

The protein structure of $2 \mathrm{QMJ}$ was obtained from Protein Data Bank (PDB) with the resolution of $1.9 \AA$ bound with the ligand 1,4-deoxy-4-((5-hydroxymethyl-2,3,4-trihydroxycyclohex-5,6 enyl)amino) fructose and prepared using Discovery Studio Visualizer ${ }^{16}$ and was used for the optimization and minimization until the root mean square deviation reached 2.0 §. Then, Grid was generated using Grid generation Wizard for docking studies. 
RASĀYAN J. Chem.

Vol. 13 | No. 1 |690 - 698| January - March | 2020

Molecular Docking

Molecular docking was carried out by using the AutoDock 4.2. ${ }^{17}$ In this program, docking was chosen according to default. Dimension of grid box was $(60 \times 60 \times 60) \AA$ and $X=18.738 \AA, Y=-7.053 \AA$, and $Z=-4.05 \AA$ as coordinate.

\section{Simulations}

The MD simulation was carried out by using The AMBER 18 software package. ${ }^{18}$ The initial structures of 34, 36, 43, and $\mathbf{5 6}$ complexes from the docked results were used for the MD simulations. The FF14SB AMBER force field was taken from the protein, and charges were added to the protein by using the software database. The general AMBER force field (GAFF2) was taken for ligands ${ }^{19}$, and AM1-BCC method was applied to assign their partial charges because of the lack of partial charge parameters for ligands in GAFF2 force field. ${ }^{20}$ The Antechamber suite (AMBER 18 package) was used to produce the atomic charges and topology files of ligands. ${ }^{19}$ The Tleap module of the AMBER 18 was used to produce the topology and coordinate files of the whole system.

The whole system was dipped into a water box of TIP3P with a margin distance of $10 \AA .{ }^{21}$ To neutralize the charge of the system, a proper number of natrium ions were added. The particle mesh Ewald (PME) was adopted during the MD simulations to deal with the long-range electrostatic interactions ${ }^{22}$, and the cut-off distance of nonbonded interactions was set to $10 \AA$. The SHAKE algorithm was used to constrain the bonds involving hydrogen. ${ }^{23}$

Firstly, two-stage energy minimizations were performed on each system: the algorithms $(1,000$ steps of the steepest descent and 1,000 steps of the conjugate gradient) with restrain were performed in the first stage; the same algorithms without restrain were further used in the second stage. Secondly, each system was heated from 0 to $300 \mathrm{~K}$ within 20 picoseconds (ps), gradually.

Then, the system was equilibrated up to $100 \mathrm{ps}$ at $300 \mathrm{~K}$ and constant pressure. Finally, a production process of $50 \mathrm{~ns}$ was performed in the constant temperature and pressure (NTP) with a step of $2 \mathrm{fs}$. The trajectories were recorded every $10 \mathrm{ps}$ and the stability of the system was checked by the RMSD of the backbone. Trajectory analysis was carried out by using the CPPTRAJ. ${ }^{24}$

\section{Calculation of Binding Free Energy}

The MM-GBSA method in AMBER 18 was used to compute the binding free energies of the receptorligand complexes. ${ }^{25}$ All the 100 snapshots of the simulated structures within the last $1 \mathrm{~ns}$ trajectory of MD simulations were extracted to perform the binding free energies calculations.

\section{Molecular Docking}

\section{RESULTS AND DISCUSSION}

Molecular docking is done to predict the orientation of one molecule into the receptor and its interaction is evaluated based on conformation and electrostatic properties. ${ }^{26}$ Native ligan, 1,4-deoxy-4((5hydroxymethyl-2,3,4-trihydroxycyclohex-5,6-enyl)amino) fructose (acarbose) was docked into the binding site of alpha-glucosidase (PDB: 2QMJ) receptor ${ }^{27}$ for validating the docking method. The rootmean-square deviation (RMSD) between the docked structure (red color) and the X-ray crystal structure (green color) of acarbose was $1.52 \AA$ (less than $2 \AA$ ) (Fig.-1), which is satisfactory. The smaller RMSD shows the position of the re-docking ligand which is getting closer to the position of the crystallographic igand. $^{13}$

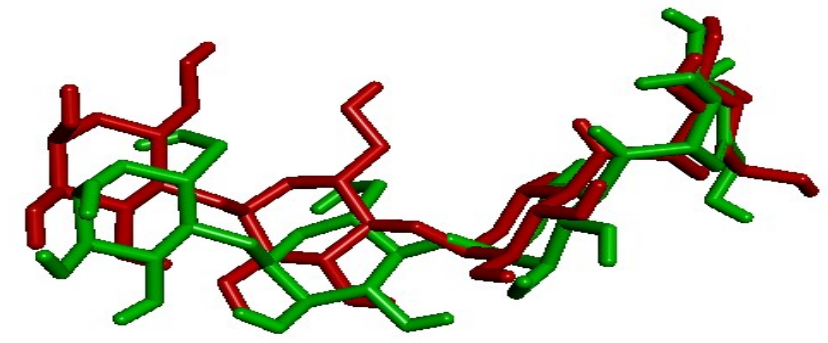

Fig.-1: Overlay of Docked Structure (Red Color) and the X-ray Crystal Structure (Green Color) of Acarboseare Quite Similar.

692 
RASĀYAN J. Chem.

Vol. 13 | No. 1 |690-698| January - March | 2020

Also, all the 57 curculigosides $\mathrm{A}^{9}$ were docked into the binding pocket of alpha glucosidase (Table-1). To illustrate the interaction between ligands and alpha glucosidase, all docking mode were formed bonding to amino acid residues Asp327, Asp203, Arg526, Asp542, and His600; obtained the four best compounds, i.e. 34 (3,5-dihydroxybenzyl-4-chlorobenzoate), 36 (3,5-dihydroxybenzyl-3-bromobenzoate), 43 (3,5dihydroxybenzyl-4-(tert-butyl)benzoate), and $\mathbf{5 6}$ (4-hydroxybenzyl-4-(tert-butyl)benzoate) with free binding energy ( $\mathrm{kcal} / \mathrm{mole})$ of $-6.74,-6.69,-6.81$, and -6.68 , respectively.

Table-1: Interaction Properties between Ligands and Alpha Glucosidase

\begin{tabular}{|c|c|c|c|c|c|}
\hline \multirow[b]{2}{*}{ Ligands } & \multirow[b]{2}{*}{$\begin{array}{c}\Delta \mathrm{G} \\
(\mathrm{Kcal} / \mathrm{mole})\end{array}$} & \multicolumn{3}{|c|}{ H-Bond } & \multirow[b]{2}{*}{ Amino Acid Residues } \\
\hline & & Donor & Acceptor & $\begin{array}{c}\text { Length } \\
(\AA)\end{array}$ & \\
\hline \multirow{10}{*}{$\begin{array}{c}\text { Native Ligand } \\
\text { (Acarbose) }\end{array}$} & \multirow{10}{*}{$-4,88$} & $\mathrm{OH}$ & O (Asp203) & 2.05179 & \multirow{10}{*}{$\begin{array}{l}\text { Asp203, Thr205, } \\
\text { Asn207, Tyr299, } \\
\text { Asp327, Ile328, } \\
\text { Trp406, Trp441, } \\
\text { Asp443, Met444, } \\
\text { Ser448, Phe450, } \\
\text { Arg526, Trp535, } \\
\text { Asp542, Asp571, } \\
\text { Phe575, Arg598, } \\
\text { His600 }\end{array}$} \\
\hline & & $\mathrm{OH}$ & O(Asp203) & 2.10537 & \\
\hline & & $\mathrm{NH}$ & $\mathrm{O}(\mathrm{Asp} 542)$ & 2.40579 & \\
\hline & & $\mathrm{NH}$ & $\mathrm{O}($ Asp542) & 1.92847 & \\
\hline & & $\mathrm{OH}$ & $\mathrm{O}(\mathrm{Asp} 542)$ & 2.02195 & \\
\hline & & $\mathrm{OH}$ & $\mathrm{O}(\mathrm{Asp} 327)$ & 2.1414 & \\
\hline & & NH(Arg526) & $\mathrm{O}(\mathrm{OH})$ & 1.78717 & \\
\hline & & NH(Arg526) & $\mathrm{O}(\mathrm{OH})$ & 2.18891 & \\
\hline & & NH(His600) & $\mathrm{O}(\mathrm{OH})$ & 2.07274 & \\
\hline & & NH(His600) & $\mathrm{O}(\mathrm{OH})$ & 2.18926 & \\
\hline \multirow[b]{4}{*}{34} & \multirow[b]{4}{*}{-6.74} & $\mathrm{OH}$ & $\mathrm{O}($ Asp443) & 1.94482 & \multirow{4}{*}{$\begin{array}{l}\text { Tyr299, Asp327, } \\
\text { Trp406, Trp441, } \\
\text { Asp443, Met444, } \\
\text { Arg526, Trp539, } \\
\text { Asp542, Phe575, } \\
\text { His600, Gln603, } \\
\text { Tyr605 }\end{array}$} \\
\hline & & $\mathrm{OH}$ & $\mathrm{O}(\mathrm{Asp} 327)$ & 1.89379 & \\
\hline & & NH(Arg526) & $\mathrm{O}(\mathrm{OH})$ & 2.02255 & \\
\hline & & NH(His600) & $\mathrm{O}(\mathrm{OH})$ & 1.90908 & \\
\hline \multirow{5}{*}{36} & \multirow{5}{*}{-6.69} & $\mathrm{OH}$ & $\mathrm{O}($ Asp443) & 1.99091 & \multirow{5}{*}{$\begin{array}{l}\text { Asp203, Tyr299, } \\
\text { Asp327, Ile364, } \\
\text { Asp366, Trp406, } \\
\text { Trp441, Asp443, } \\
\text { Met444, Phe450, } \\
\text { Arg526, Asp542, } \\
\text { Phe575, His600 }\end{array}$} \\
\hline & & $\mathrm{OH}$ & $\mathrm{O}(\mathrm{Asp} 327)$ & 1.8032 & \\
\hline & & NH(Trp406) & $\mathrm{O}(\mathrm{H})$ & 2.42645 & \\
\hline & & NH(Arg526) & $\mathrm{O}(\mathrm{CO})$ & 1.86545 & \\
\hline & & NH(His600) & $\mathrm{O}(\mathrm{OH})$ & 1.96354 & \\
\hline \multirow[b]{4}{*}{43} & \multirow[b]{4}{*}{-6.81} & $\mathrm{OH}$ & $\mathrm{O}($ Ser448) & 1.90706 & \multirow{4}{*}{$\begin{array}{l}\text { Arg202, Asp203, } \\
\text { Thr204, Tyr299, } \\
\text { Asp327, Ile364, } \\
\text { Trp406, Trp441, } \\
\text { Asp443, Met444, } \\
\text { Ser448, Asn449, } \\
\text { Phe450, Lys480, } \\
\text { Arg526, Asp542, } \\
\text { His600 }\end{array}$} \\
\hline & & $\mathrm{OH}$ & $\mathrm{O}($ Asp203) & 1.78573 & \\
\hline & & NH(Arg202) & $\mathrm{O}(\mathrm{OH})$ & 2.36903 & \\
\hline & & O(Asp327) & $\mathrm{CH}_{3}$ & 3.276 & \\
\hline \multirow[b]{2}{*}{56} & & $\mathrm{OH}$ & $\mathrm{O}(\mathrm{Asp} 203)$ & 1.71955 & \multirow[b]{2}{*}{$\begin{array}{l}\text { Arg202, Asp203, } \\
\text { Thr204, Tyr299, } \\
\text { Asp327, Ile364, } \\
\text { Trp406, Trp441, } \\
\text { Asp443, Met444, } \\
\text { Ser448, Phe450, } \\
\text { Lys480, Arg526, } \\
\text { Asp542, Phe575, } \\
\text { His600 }\end{array}$} \\
\hline & -6.68 & NH(Arg202) & $\mathrm{O}(\mathrm{OH})$ & 2.13038 & \\
\hline
\end{tabular}

Native ligand has a docking mode for amino acid residues on the active site of the receptor. These ligandreceptor interactions are formed through hydrogen bonds, Van der Waals bonds and or electrostatic 693 
RASĀYAN J. Chem.

Vol. 13 | No. 1 |690 - 698| January - March | 2020

interactions (Fig.-2) and ligands 34, 36, 43, and 56 have docking modes similar to native ligand (acarbose). Aglycone curculigoside A has a planar-shaped aromatic ring (Table-2) which able to form van der Waals interaction and $\pi$-interactions. Asp 542 residue formed $\pi$-anion interaction to 34, 36, 43, and 56 . The $\pi$-anion interaction plays a role in the stability of the binding interaction. ${ }^{28}$

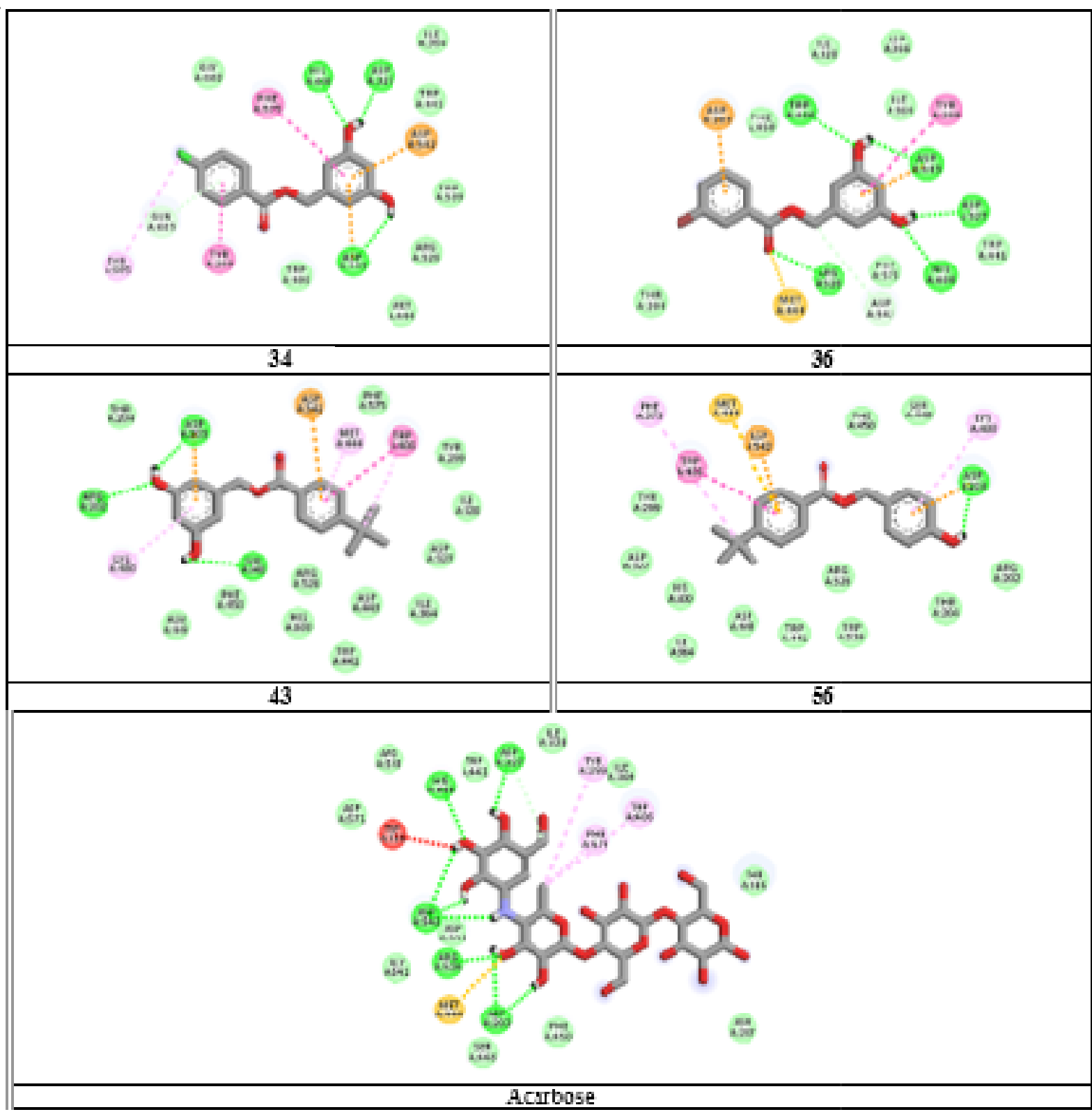

Fig.-2: Docking Mode of 34, 36, 43, 56, and Native Ligand (Acarbose) into the Active Site of Alpha Glucosidase.

Asp327 residues form hydrogen bonds to $\mathrm{O}$ atoms in hydroxyl groups substituted in benzene in $\mathbf{3 4}, \mathbf{3 6}$, 43, and 56 as well as in Asp327, His600, and Arg526 residues. Based on these results, ligand 34, 36, 43, and 56 were able to interact with amino acid residues (key residues) in the binding pocket of alpha glucosidase via hydrogen bonds to the Asp327, Asp542, Arg526 and His600 residues which are important amino acid residues on the active side of alpha glucosidase. ${ }^{27}$

The 34, 36, 43, and 56 have a value of free bonding energy higher than the value in the native ligand ($4.88 \mathrm{kcal} / \mathrm{mole}$ ). These results indicate that compound 34, 36, $\mathbf{4 3}$, and $\mathbf{5 6}$ have a good affinity for alpha glucosidase receptors. Free bonding energy $(\Delta \mathrm{G})$ shows the stability of the ligand (bond) interaction to the 
RASĀYAN J. Chem.

Vol. 13 | No. 1 |690-698| January - March | 2020

alpha glucosidase enzyme into the binding site. The higher the value of free bonding energy, the more stable interaction of ligand-receptor. ${ }^{29}$

\section{Simulations}

\section{Simulations Features}

Molecular dynamics simulations were carried out to explore receptor-ligand interactions by considering protein flexibility. To observe the stability of the complexes, the properties of each complex (such as pressure, temperature, structure, and energy) were examined during the entire MD trajectory (Fig.-3). This simulation was carried out on protein-ligands complexes (acarbose, 34, 36, 43, and 56). The RMSD value of backbone atom referring to the starting structure of the protein-ligand complex was used to monitor the dynamic stability of the MD trajectories. The average RMSD fluctuations for the protein and ligand (acarbose, 34, 36, 43, and 56) are $1.36 \AA$ and $1.91 \AA ; 1.60 \AA$ and $1.57 \AA ; 1.28 \AA$ and $1.71 \AA ; 1.33$ $\AA$ and $1.72 \AA$; and $1.30 \AA$ and $1.28 \AA$, respectively. These results reveal the average RMSD fluctuations of the five ligands: $\mathbf{5 6}<\mathbf{3 4}<\mathbf{4 3}<\mathbf{3 6}<$ acarbose.

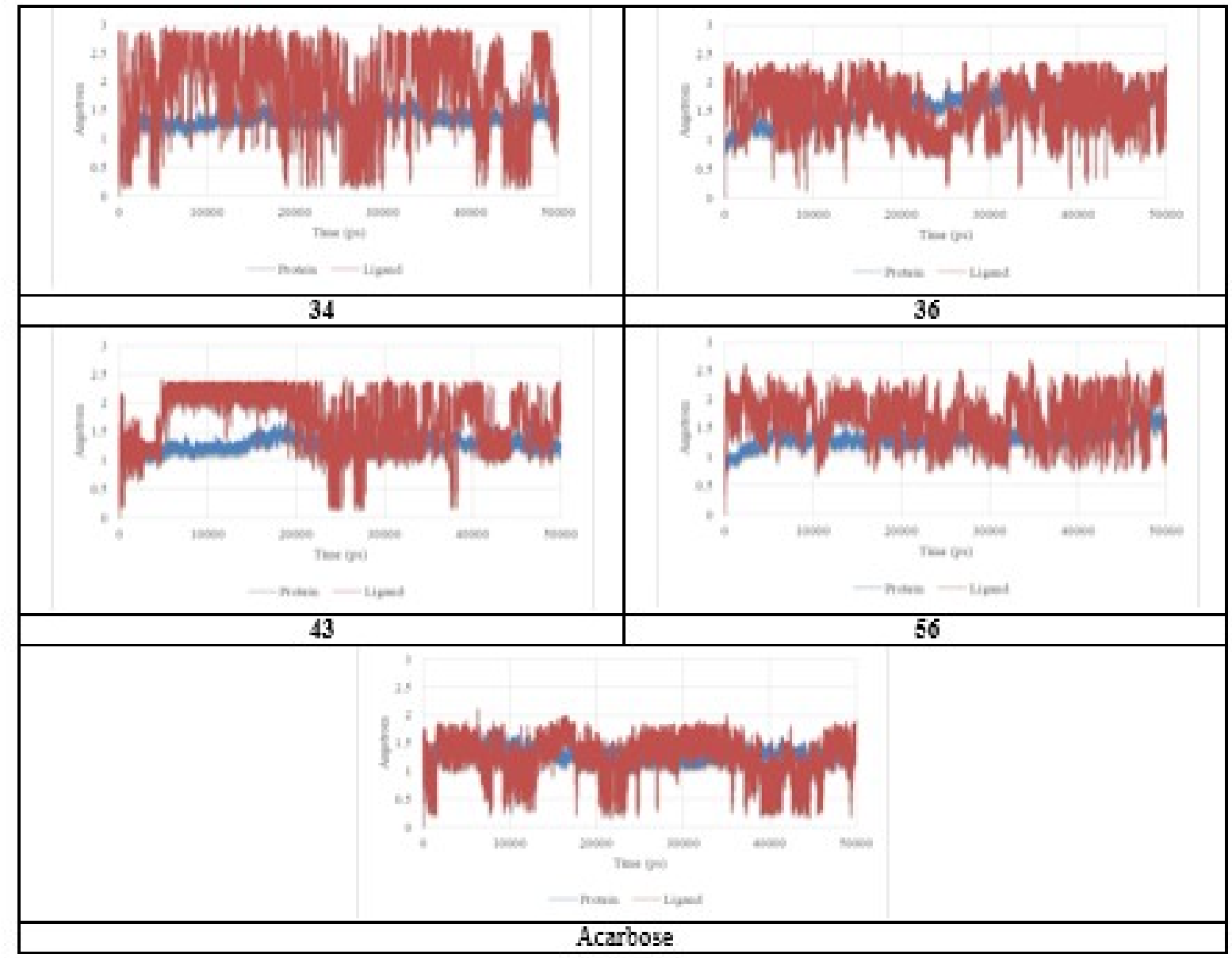

Fig.-3: RMSD Versus Time for the Acarbose, 34, 36, 43, and $\mathbf{5 6 .}$

\section{RMSF (Stability of the Binding Pocket)}

The root-mean-squared (RMSF) was used to explore the stability of the binding pocket during the MD simulation process. The RMSF of all residues around the acarbose, 34, 36, 43, and 56 complexes were computed within the last $10 \mathrm{~ns}$ trajectory of MD simulations by using Discovery Studio. The residues around the ligand and their RMSF values compared to the initial complexes can be seen in Table 2. In all 
RASĀYAN J. Chem.

Vol. 13 | No. 1 |690-698| January - March | 2020

the complexes, the RMSF for each residue surrounding the ligand is lower than $1.5 \AA$ (Table-2), which means that the binding pocket is stable during the MD simulation.

Table-2: RMSF Values $(\AA)$ and Residues of the Binding Pocket

\begin{tabular}{l|l|l|l|l|l}
\hline Residues & Mol 1 & Mol 2 & Mol 3 & Mol 4 & Mol 5 \\
\hline LEU 401 & 0.575 & 0.787 & 0.644 & 0.610 & 0.565 \\
\hline ILE 402 & 0.563 & 0.804 & 0.650 & 0.613 & 0.564 \\
\hline GLY 403 & 0.553 & 0.782 & 0.635 & 0.590 & 0.570 \\
\hline GLU 404 & 0.584 & 0.807 & 0.662 & 0.635 & 0.624 \\
\hline GLN 409 & 0.695 & 0.755 & 0.757 & 0.677 & 0.666 \\
\hline PHE 412 & 0.512 & 0.662 & 0.537 & 0.498 & 0.504 \\
\hline ASN 442 & 0.496 & 0.743 & 0.601 & 0.523 & 0.535 \\
\hline PHE 450 & 0.583 & 0.831 & 0.658 & 0.627 & 0.633 \\
\hline VAL 451 & 0.587 & 0.823 & 0.665 & 0.652 & 0.643 \\
\hline ASP 452 & 0.567 & 0.797 & 0.680 & 0.650 & 0.592 \\
\hline GLY 453 & 0.542 & 0.781 & 0.654 & 0.613 & 0.554 \\
\hline SER 454 & 0.591 & 0.865 & 0.703 & 0.647 & 0.617 \\
\hline VAL 455 & 0.695 & 0.990 & 0.816 & 0.772 & 0.742 \\
\hline SER 456 & 0.918 & 1.256 & 0.948 & 1.053 & 1.051 \\
\hline GLY 457 & 0.897 & 1.236 & 0.905 & 0.990 & 1.043 \\
\hline CYS 458 & 0.769 & 1.065 & 0.851 & 0.872 & 0.846 \\
\hline SER 459 & 0.805 & 1.012 & 0.950 & 0.974 & 0.857 \\
\hline ASN 464 & 0.560 & 0.748 & 0.635 & 0.644 & 0.567 \\
\hline PHE 478 & 0.497 & 0.783 & 0.610 & 0.599 & 0.536 \\
\hline THR 481 & 0.446 & 0.724 & 0.546 & 0.497 & 0.476 \\
\hline LEU 482 & 0.458 & 0.719 & 0.553 & 0.494 & 0.472 \\
\hline CYS 483 & 0.478 & 0.747 & 0.587 & 0.548 & 0.502 \\
\hline ASP 484 & 0.516 & 0.771 & 0.617 & 0.594 & 0.542 \\
\hline
\end{tabular}

\section{Hydrogen Bonds Interaction}

Hydrogen bonds interaction plays important role in the complexes between receptor and ligand. Hydrogen bonds were computed within the last $10 \mathrm{~ns}$ trajectory. All the possible hydrogen acceptors were taken into consideration, such as protein, ligands, and water molecules. The results of hydrogen bonds analysis for the five systems are listed in Table-3.

There were five, three, six, three, and one hydrogen bonds formed in acarbose, 34, 36, 43, and 56, respectively (Table-2). The hydrogen bonds formed in complexes (MD simulation) are quite different compared to the binding mode (docking simulation), because of a large movement of ligand and receptor during the MD simulation.

Table-3: Hydrogen Bonds Analysis for Acarbose, 34, 36, 43, and 56

\begin{tabular}{c|l|l|c|c}
\hline Complex & \multicolumn{1}{|c|}{ Acceptor } & \multicolumn{1}{|c}{ Donor } & Lenght $(\AA)$ & Angle $\left(^{\circ}\right)$ \\
\hline Mol 1 & Lig C=O & LYS 195 N-H1 & 2.90 & 144.97 \\
\hline & Lig C=O & ASP474 N-H2 & 2.83 & 107.67 \\
\hline & ARG 471 C $=\mathrm{O}$ & Lig N1-H & 2.06 & 167.68 \\
\hline
\end{tabular}


RASĀYAN J. Chem.

Vol. 13 | No. 1 |690-698| January - March | 2020

\begin{tabular}{c|l|l|c|c}
\hline & Lig C=O & LYS 195 N-H3 & 2.17 & 115.70 \\
\hline & Lig C=O & ASP474 N-H4 & 1.84 & 96.45 \\
\hline Mo1 2 & ASP443 C=O & Lig N1-H & 1.94 & 159.91 \\
\hline & ASP327 C=O & Lig N2-H & 1.89 & 126.99 \\
\hline & Lig C=O & HIS 600 N-H1 & 1.91 & 140.19 \\
\hline & Lig C=O & ARG 526 N-H1 & 2.88 & 165.93 \\
\hline & ASP 443 C=O & Lig N1-H & 1.99 & 137.88 \\
\hline & ASP 327 C=O & Lig N2-H & 1.80 & 174.54 \\
\hline & Lig C $=\mathrm{O}$ & TRP 406 N-H2 & 2.43 & 118.34 \\
\hline & Lig C=O & ARG 526 N-H3 & 1.87 & 171.42 \\
\hline & Lig C=O & HIS 600 N-H4 & 1.96 & 145.07 \\
\hline & SER 448 C=O & Lig N1-H & 1.91 & 176.76 \\
\hline & ASP 203 C=O & Lig N2-H & 1.79 & 151.67 \\
\hline & Lig C $=\mathrm{O}$ & ARG 202 N-H1 & 2.37 & 120.70 \\
\hline & ASP 203 C=O & Lig N1-H & 1.72 & 158.13 \\
\hline
\end{tabular}

\section{Binding Free Energies}

The calculated $\Delta \mathrm{G}_{\text {bind }}$ of the five complexes was carried out by using MMGBSA method (Table-3), involved $\Delta \mathrm{E}_{\mathrm{vdw}}, \Delta \mathrm{E}_{\text {ele }}, \Delta \mathrm{G}_{\mathrm{GB}}, \Delta \mathrm{G}_{\mathrm{SA}}, \Delta \mathrm{E}_{\text {gas }}, \Delta \mathrm{G}_{\mathrm{sol}}$, and $\Delta \mathrm{G}_{\mathrm{bind}}$. The van der Waals interactions occur when adjacent atoms come close enough that their outer electron clouds just barely touch. The $\mathbf{5 6}$ complex has the lowest van der Waals energy of $-18.38 \mathrm{kcal} / \mathrm{mole}$ which is influenced by hydrophobic interactions between $t$-butoxy benzyl with residues surrounding 56. The $\mathbf{4 3}$ complex has a van der Waals energy of $-15.36 \mathrm{kcal} / \mathrm{mole}$ which is influenced by the hydrophobic interaction between methoxy benzyl with residues surrounding $\mathbf{4 3}$. The $\mathbf{3 6}$ complex has a van der Waals energy of $-12.50 \mathrm{kcal} / \mathrm{mole}$ which is influenced by the hydrophobic interaction between dihydroxy benzyl with residues surrounding 36 . The 34 complex has a van der Waals energy of $-10.88 \mathrm{kcal} / \mathrm{mole}$ which is influenced by hydrophobic interactions between dihydroxy benzyl with residues surrounding 34. Acarbose complex has the highest van der Waals energy that is $-6.01 \mathrm{kcal} / \mathrm{mole}$ which is influenced by hydrophobic interactions between dihydroxy benzyl with residues surrounding acarbose.

The electrostatic also affects free binding energy because each complex shows the presence of hydrogen bonds with the receptor as well as unfavorable polar solvation $\left(\Delta \mathrm{G}_{\mathrm{GB}}\right)$ (e.g. 34 and 36 complexes). The 34 complex has a low electrostatic value, but the free binding energy is higher than $\mathbf{3 6}$ complex because it has a high in $\Delta \mathrm{G}_{\mathrm{GB}}$ whereas non-polar solvation contributions $\left(\Delta \mathrm{G}_{\mathrm{SA}}\right)$ do not affect bond free energy.

\section{CONCLUSION}

In conclusion, the binding modes of four inhibitors $(\mathbf{3 4}, \mathbf{3 6}, \mathbf{4 3}$, and $\mathbf{5 6})$ in docking simulation are similar; and RMSD fluctuations (MD simulation) of the four complexes are consistent with their inhibitory activities. Therefore, these ligands can be considered as a lead compound for alpha-glucosidase inhibitors.

\section{ACKNOWLEDGMENT}

This research was supported by the Ministry of Research, Technology, and Higher Education, Republic of Indonesia (Riset Penelitian Dasar Tahun 2019).

\section{REFERENCES}

1. M. Khajedaluee, M. Dadgarmoghaddam, R. Saeedi, Z. Izadi-Mood and M. Abrishami, Open Journal of Preventive Medicine, 4(04), 175(2014), DOI: 10.4236/ojpm.2014.44023

2. T. Scully, Nature, 485, S2(2012), DOI: $10.1038 / 485$ S2a

3. A. Ceriello and S. Genovese, Reviews in Endocrine and Metabolic Disorders, 17(1), 111(2016), DOI: $10.1007 / \mathrm{s} 11154-016-9341-8$ 
RASĀYAN J. Chem.

Vol. 13 | No. 1 |690-698| January - March | 2020

4. L. Chen, B. Tuo and H. Dong, Nutrients, 8(1), 43(2016), DOI: 10.3390/nu8010043

5. B.G. Katzung, Basic and Clinical Pharmacology, McGraw-Hill Education, New York, (2017).

6. V. Mehta, A. Parashar and M. Udayabanu, Physiology \& Behavior, 171, 69(2017), DOI: 10.1016/j.physbeh.2017.01.006

7. M. Liu, H. Yin, G. Liu, J. Dong, Z. Qian and J. Miao, Journal of Agricultural and Food Chemistry, 62(24), 5548(2014), DOI:10.1021/jf500426z

8. R.W. Wong, B. Rabie, M. Bendeus and U. Hägg, Chinese Medicine, 2(1), 13(2007), DOI: $10.1186 / 1749-8546-2-13$

9. N. Nursamsiar, S. Ibrahim and D.H. Tjahjono, Jurnal Farmasi Indonesia, 7(2), 16(2014), DOI: $10.35617 /$ jifi.v7i2.171

10. M.A. Johnson and G.M. Maggiora, Concepts and Applications of Molecular Similarity, Wiley, New York, (1990).

11. A. Asnawi, R.E. Kartasasmita, A. Nawawi and S. Ibrahim, Journal of Mathematical and Fundamental Sciences, 43(1), 43(2011), DOI: 10.5614\%2Fitbj.sci.2011.43.1.4

12. F.Z. Muttaqin, S.I. Surantaatmadja, A. Mutalib and D.H. Tjahjono, In Proceedings of $3 r d$ International Conference on Computation for Science and Technology (ICCST-3), Atlantis Press, (2015), DOI: 10.2991/iccst-15.2015.6

13. M. Kontoyianni, L.M. McClellan and G.S. Sokol, Journal of Medicinal Chemistry, 47(3), 558(2004), DOI: $10.1021 /$ acs.jcim.9b00383

14. M.L. Teodoro, G.N. Phillips and L.E. Kavraki, In Proceedings 2001 ICRA. IEEE International Conference on Robotics and Automation, 1, 960(2001), DOI:10.1109/ROBOT.2001.932674

15. C.D. Ultra, C. D. 8.0., Cambridge Soft Corporation, USA, (2015).

16. D.S. Biovia, Discovery studio visualizer. San Diego, CA, USA, (2017).

17. G.M. Morris, R. Huey, W. Lindstrom, M.F. Sanner, R.K. Belew, D.S. Goodsell and A.J. Olson, Journal of Computational Chemistry, 30(16), 2785(2009), DOI: 10.1002/jcc.21256

18. T.S. Lee, D.S. Cerutti, D. Mermelstein, C. Lin, S. LeGrand, T.J. Giese, A. Roitberg, D.A. Case, R.C. Walker and D.M. York, Journal of Chemical Information and Modeling, 58(10), 2043(2018), DOI: 10.1021/acs.jcim.8b00462

19. J. Wang, R.M. Wolf, J.W. Caldwell, P.A. Kollman and D.A. Case, Journal of Computational Chemistry, 25(9), 1157(2004), DOI: 10.1002/jcc.20035

20. A. Jakalian, B.L. Bush, D.B. Jack and C.I. Bayly, Journal of Computational Chemistry, 21(2), 132(2000), DOI: 10.1002/(SICI)1096-987X(20000130)21:2<132::AID-JCC5>3.0.CO;2-P

21. W.L. Jorgensen, J. Chandrasekhar, J.D. Madura, R.W. Impey and M.L. Klein, The Journal of Chemical Physics, 79(2), 926(1983), DOI: 10.1063/1.445869

22. T. Darden, D. York and L. Pedersen, The Journal of Chemical Physics, 98(12), 10089(1993), DOI: $10.1063 / 1.464397$

23. J.P. Ryckaert, G. Ciccotti and H.J. Berendsen, Journal of Computational Physics, 23(3), 327(1977), DOI: $10.1016 / 0021-9991(77) 90098-5$

24. D.R. Roe and T.E. Cheatham III, Journal of Chemical Theory and Computation, 9(7), 3084(2013), DOI: $10.1021 / \mathrm{ct} 400341 \mathrm{p}$

25. B.R. Miller III, T.J. McGee Jr, J.M. Swails, N. Homeyer, H. Gohlke and A.E. Roitberg, Journal of Chemical Theory and Computation, 8(9), 3314(2012), DOI: 10.1021/ct300418h

26. K. Saravanan, C. Kalaiarasi and P. Kumaradhas, Journal of Biomolecular Structure and Dynamics, 35(16), 3627(2017), DOI: 10.1080/07391102.2016.1264891

27. L. Sim, R. Quezada-Calvillo, E.E. Sterchi, E.E., B.L. Nichols and D.R. Rose, Journal of Molecular Biology, 375(3), 782(2008), DOI:10.1016/j.jmb.2007.10.069

28. X. Liu, D.C. Speckhard, T.R. Shepherd, Y.J. Sun, S.R. Hengel, L. Yu, C.A. Fowler, L. Gakhar and E.J. Fuentes, Structure, 24(12), 2053(2016), DOI:10.1016/j.str.2016.08.019

29. X. Du, Y. Li, Y.L. Xia, S.M. Ai, J. Liang, P. Sang, X.L. Ji and S.Q. Liu, International Journal of Molecular Sciences, 17(2), 144(2016), DOI:10.3390/ijms17020144

[RJC-5577/2019] 